mechanism linking stress and subtle alterations of lipid concentrations.

This study was carried out in collaboration with Drs F Wells, R Mercer, and D Mukerji, Orchard Street Health Centre, Ipswich, Suffolk, who provided all the patients.

We are grateful for the financial support provided for this study by an East Anglian Regional Health Authority research grant and grants from ICI and Stuart/Geigy Pharmaceuticals. We thank Miss C Gibbons for preparing the manuscript, and Mrs $\mathrm{H}$ Humphries for technical help.

\section{References}

${ }^{1}$ Day JL, Simpson N, Metcalfe J, Page RL. Metabolic consequences of atenolol and propranolol in treatment of hypertension. $\mathrm{Br}$ Med $\mathcal{F}$ $1979 ; \mathrm{i}: 77-80$.

${ }^{2}$ Leren P, Foss PO, Helgeland A, Hjermann I, Holme I, Lund-Larsen PG. Effect of propranolol and prazosin on blood lipids. Lancet 1980;ii:4-6.

${ }^{3}$ Shaw J, England JDF, Hua ASP. Beta-blockers and plasma triglycerides. Br Med f 1978; ; 986 .

${ }^{4}$ Lehtonen A, Viikan J. Long term effects of sotalol on plasma lipids. Clin Sci $1979 ; 57: 405-7 s$.

5 McGonigle RJS, Williams L, Murphy MJ, Parsans V. Labetalol and lipids. Lancet 1981 ; : 163.

${ }^{6}$ Ames RP, Hill P. Increase in serum lipids during treatment of hypertension with chlorthalidone. Lancet 1976; i:721-3.

${ }^{7}$ Lewis B, Boberg J, Mancini M, Carlson LA. Determination of the intravenous fat tolerance test with intralipid by nephelometry. Atherosclerosis $1972 ; 15: 83-6$.

${ }^{8}$ Burstein M, Samaille J. Sur un dosage rapide du cholesterol lie aux et aux $\beta$-lipoproteines du serum. Clin Chim Acta 1960;5:609.

9 Wilson DE, Spiger MJ. A dual precipitation method for quantitative plasma lipoprotein measurement without ultracentrifugation. $\mathcal{f} L a b$ Clin Med $1973 ; 82: 473-82$.
10 Hallberg D. Studies on the elimination of exogenous lipids from the blood stream. The kinetics of the elimination of a fat emulsion by a constant infusion technique in man. Acta Physiol Scand 1965;64:306-13.

11 Boberg J, Carlson LA, Hallberg D. Application of a new intravenous fat tolerance test in the study of hypertriglyceridaemia in man. Fournal of Atherosclerosis Research 1969;9:159-69.

${ }^{12}$ Erkelens DW, Brunzell JD, Bierman EL. Availability of apolipoprotein CII in relation to the maximal removal capacity of infused triglyceride emulsion in man. Metabolism 1979;28:495-501.

13 Eisenberg S, Patsch JR, Olivecrona T, Gotto AM. Effects of lipolysis on human lipid density lipoproteins (HDL). Circulation 1978;58, suppl: abstract 47.

${ }^{14}$ Patsch JR, Gotto AM, Olivecrona T, Eisenberg S. Formation of high density lipoprotein-like particles during lipolysis of very low density lipoproteins in vitro. Proc Natl Acad Sci USA 1978;75:4519-23.

15 Tall AR, Small DM. Plasma high density lipoproteins. N Englf Med 1978; 299:1232-6.

16 Myers LH, Phillips NR, Havel RJ. Mathematical evaluation of methods for estimation of the concentration of the major lipid components of human serum lipoproteins. F Lab Clin Med 1976;88:491-505.

17 Schonfeld G, Bailey A, Steelman R. Plasma apolipoproteins, A-I and A-II levels in hyperlipidemia. Lipids 1978;13:951-9.

${ }^{18}$ Rahn KH, Gierlichs W, Planz G, Planz R, Schols M, Stephany W. Studies on the effects of propranolol on plasma catecholamine levels in patients with essential hypertension. Eur $\mathcal{F}$ Clin Invest 1978;8:143-8.

19 Ashby P, Parkin SM, Walker K, Bennett DP, Robinson DS. Hormonal control of adipose tissue lipoprotein lipase activity. INSERM Symposia $1980 ; 87: 149-60$.

${ }^{20}$ Rosenman RH, Brand RJ, Jenkins CD, Friedman H, Strauss R, Warm K. Coronary heart disease in the Western Collaboration Group Study. Final follow up experience of eight and a half years. $\mathcal{F} A M A 1975 ; \mathbf{2 3 3}$ : 872-7.

${ }^{21}$ Friedman $\mathrm{H}$, Rosenman RH. Association of specific overt behavior pattern with blood and cardiovascular findings. $\mathcal{F} A M A$ 1959;169:1286-96.

22 Friedman H, Rosenman RH, Byers SO. Serum lipids and conjugated circulation after fat ingestion in men exhibiting type A behaviour pattern. Circulation $1964 ; 29: 874-86$.

(Accepted 20 fanuary 1982)

\title{
Blood pressure and heart rate in patients with ischaemic heart disease receiving nifedipine and propranolol
}

\author{
LOUISE HARRIS, HENRY J DARGIE, PETER G LYNCH, CHRISTOPHER J BULPITT, \\ DENNIS M KRIKLER
}

\begin{abstract}
A randomised controlled crossover trial was performed to assess the anti-anginal effects of nifedipine and propranolol separately and together. The effects of these treatments on blood pressure and heart rate were assessed at rest and after the cold pressor and mental arithmetic tests. Nifedipine and propranolol together produced the greatest reduction in supine and erect systolic and diastolic blood pressures. Propranolol (480 mg daily) lowered resting systolic/diastolic blood pressures by $7 / 6 \mathrm{~mm} \mathrm{Hg}$ and nifedipine $(60 \mathrm{mg}$ daily) lowered it by $10 / 8 \mathrm{~mm} \mathrm{Hg}$, while in the erect position the
\end{abstract}

Division of Cardiovascular Disease, Royal Postgraduate Medical School, Hammersmith Hospital, London W12 0HS

LOUISE HARRIS, MB, MRCP, research fellow and honorary registrar

HENRY J DARGIE, MB, MRCP, honorary senior registrar (now consultant cardiologist, Western Infirmary, Glasgow)

PETER G LYNCH, MB, MRACP, research fellow and honorary registrar (present address: Prince Henry Hospital, Melbourne, Australia)

CHRISTOPHER J BULPITT, MD, MRCP, honorary senior lecturer, clinical pharmacology

DENNIS M KRIKLER, MD, FRCP, consultant cardiologist hypotensive effect of these agents averaged $9 / 8 \mathrm{~mm} \mathrm{Hg}$. During the cold pressor test propranolol lowered the maximum pressure by an average of $11 / 6 \mathrm{~mm} \mathrm{Hg}$ and nifedipine by $19 / 10 \mathrm{~mm} \mathrm{Hg}$. For the mental arithmetic test, the results were $7 / 2 \mathrm{~mm} \mathrm{Hg}$ and $16 / 7 \mathrm{~mm} \mathrm{Hg}$ respectively. Propranolol (480 mg daily) reduced supine and erect heart rate by 19 and 25 beats/minute respectively, while nifedipine did not alter heart rate significantly.

The favourable haemodynamic responses to nifedipine suggest that it may be of value in the management of hypertension.

\section{Introduction}

Since the principal haemodynamic abnormality in essential hypertension is an increase in peripheral vascular resistance, there is a rationale for using drugs that lower peripheral vascular resistance by a direct action on arteriolar smooth muscle. Contraction of vascular smooth muscle depends on the influx of calcium ions across the cell membrane through the "slow channels."1 Drugs which selectively block such transport, the calcium antagonists, relax vascular smooth muscle with an effect not only on peripheral vessels but also on the large 
extramural coronary arteries. ${ }^{2}$ The demonstration of increased calcium transport in arteriolar smooth muscle of rats with experimental hypertension ${ }^{3}$ provides a further stimulus to investigate the role of calcium in essential hypertension and the scope for calcium antagonists in its treatment.

In a study of the anti-anginal effects of the calcium antagonist nifedipine in comparison and in combination with propranolol ${ }^{4}$ we investigated the hypotensive effect of these agents in relation to heart rate at rest and during the cold pressor and mental arithmetic tests.

\section{Patients and methods}

We recruited 18 patients ( 15 men, 3 women, aged 41-71 (mean 58) with chronic stable exertional angina pectoris. At the end of a twoweek run-in period on placebo all showed signs of ischaemia on exercise tests and had a resting diastolic blood pressure $\leqslant 100 \mathrm{~mm} \mathrm{Hg}$ after ten minutes' quiet recumbency. No patient had a history of cardiac failure or major obstructive airways disease, and none had suffered a myocardial infarct in the six months before the study.

Trial design-Four treatments were given, each for four weeksnifedipine, propranolol, the combination of nifedipine and propranolol, and placebo. The trial was conducted double-blind and the order of administration was randomised with a Latin square balanced for order and carry-over effects. During the first two weeks of each period the agents were given at the lower doses $(10 \mathrm{mg}$ nifedipine and $80 \mathrm{mg}$ propranolol three times a day) and during the second fortnight at the higher doses $(20 \mathrm{mg}$ and $160 \mathrm{mg}$ three times a day respectively). The use of identical placebo tablets ensured that the treatments appeared visually identical to the patients at all times (double-dummy technique).

Assessments-Blood pressure was measured automatically with an Arteriosonde ultrasonic sphygmomanometer after 10 minutes' lying and 2 minutes' standing and also during cold pressor and mental arithmetic tests. In the cold pressor test one hand was immersed in iced water for two minutes, and the mental arithmetic test comprised serial subtractions. Blood pressure was recorded every 30 seconds and heart rate was counted from a continuous electrocardiographic recording. These measurements were made in a quiet clinical laboratory by the same observers at approximately the same time of day. Each patient completed a questionnaire on side effects at the end of each treatment period.
Statistical methods-The data obtained were subjected to an analysis of variance for a factorial experiment, such that the effects of nifedipine and propranolol could be determined alone and in combination, and any interaction between them could be estimated. ${ }^{5}$

\section{Results}

Supine blood pressure-The combination of nifedipine and propranolol reduced systolic and diastolic blood pressure at both low and high doses; nifedipine reduced diastolic blood pressure at the lower dose and both systolic and diastolic blood pressure at the higher dose, whereas propranolol reduced only diastolic blood pressure and only at the higher dose (table I). While the combination of nifedipine and propranolol produced the greatest reduction in blood pressure, the joint effect was additive but not synergisticthat is, there was no positive interaction. In patients whose systolic blood pressure was $100-119 \mathrm{~mm} \mathrm{Hg}$ on placebo there was little or no decrease on nifedipine, whereas those patients with systolic blood pressures of $140-180 \mathrm{~mm} \mathrm{Hg}$ on placebo had the greatest response (table II). Similarly, those patients with diastolic blood pressures of $75-84 \mathrm{~mm} \mathrm{Hg}$ on placebo had little or no change on nifedipine, whereas those with pressures of $95-105 \mathrm{~mm} \mathrm{Hg}$ had the greatest response.

Erect blood pressure-Systolic blood pressure was reduced by nifedipine and propranolol at the higher doses and by the combination of the two at both doses. Diastolic blood pressure was reduced by both treatments at low and high doses (table I). As with supine blood pressure, there was no positive interaction between propranolol and nifedipine when administered together.

Cold pressor test-On placebo all patients showed the usual haemodynamic response with a sharp rise in systolic blood pressure (mean $27.7 \pm 3.2 \mathrm{~mm} \mathrm{Hg}$ ) and a modest rise in the heart rate (mean $9.3 \pm 1.6$ beats $/ \mathrm{min}$ ). All active treatments at high doses reduced the maximum systolic and diastolic blood pressure (table III). Propranolol did not attenuate the maximum rise in diastolic blood pressure during the test, but the high dose of nifedipine reduced it by $6 \mathrm{~mm} \mathrm{Hg}$ $(\mathrm{p}<0.05)$.

Mental arithmetic test-The haemodynamic response to the mental arithmetic test during placebo was similar to the response seen with the cold pressor test (table III). The combination (in high doses) significantly reduced the maximum systolic and diastolic blood pressure but did not significantly attenuate the maximum increase in blood pressure during the test. The effect of the combination was

TABLE I-Supine and erect blood pressure in response to propranolol, nifedipine, and their combination

\begin{tabular}{|c|c|c|c|c|c|c|c|}
\hline & \multicolumn{5}{|c|}{ Mean $( \pm$ SEM) blood pressures $(\mathrm{mm} \mathrm{Hg})$ on: } & \multirow{2}{*}{$\begin{array}{l}\text { Effect of } \\
\text { propranolol }\end{array}$} & \multirow{2}{*}{$\begin{array}{c}\text { Effect of } \\
\text { Nifedipine }\end{array}$} \\
\hline & & Placebo & Propranolol & Nifedipine & Combination & & \\
\hline \multicolumn{8}{|c|}{ Supine blood pressure } \\
\hline $\begin{array}{cc}\text { Low dose } & \ldots \\
\text { High dose } & \cdots\end{array}$ & $\because$ & $\begin{array}{l}134 \cdot 3 \pm 4 \cdot 6 \\
133 \cdot 6 \pm 4 \cdot 2\end{array}$ & $\begin{array}{l}132 \cdot 2 \pm 4 \cdot 2 \\
128 \cdot 2 \pm 5 \cdot 1\end{array}$ & $\begin{array}{l}128 \cdot 4 \pm 3 \cdot 1 \\
124 \cdot 9 \pm 2 \cdot 6\end{array}$ & $\begin{array}{l}118 \cdot 7 \pm 3 \cdot 2 \\
115 \cdot 8 \pm 3 \cdot 8\end{array}$ & $\begin{array}{l}-5 \cdot 9 \\
-7 \cdot 3\end{array}$ & $\begin{array}{l}-9 \cdot 7 \\
-10 \cdot 6 * *\end{array}$ \\
\hline $\begin{array}{cc}\text { Diastolic pressure } \\
\text { Low dose } & \cdots \\
\text { High dose } & \cdots\end{array}$ & $\because$ & $\begin{array}{l}87 \cdot 6 \pm 2 \cdot 3 \\
88 \cdot 6 \pm 2 \cdot 2\end{array}$ & $\begin{array}{l}86 \cdot 3 \pm 2 \cdot 0 \\
82 \cdot 3 \pm 2 \cdot 2\end{array}$ & $\begin{array}{c}83.8 \pm 1.5 \\
80.6 \pm 1 \cdot 6 \\
\text { blood pressure }\end{array}$ & $\begin{array}{l}78 \cdot 9 \pm 1 \cdot 8 \\
75 \cdot 8 \pm 2 \cdot 2\end{array}$ & $\begin{array}{l}-3 \cdot 1 \\
-5 \cdot 6 * *\end{array}$ & $\begin{array}{l}-5 \cdot 6^{* *} \\
-7 \cdot 3^{* * *}\end{array}$ \\
\hline $\begin{array}{c}\text { Systolic pressure } \\
\text { Low dose } \\
\text { High dose }\end{array}$ & $\because$ & $\begin{array}{l}134 \cdot 8 \pm 4 \cdot 4 \\
134 \cdot 8 \pm 4 \cdot 6\end{array}$ & $\begin{array}{l}130 \cdot 6 \pm 5 \cdot 1 \\
128 \cdot 8 \pm 5 \cdot 4\end{array}$ & $\begin{array}{l}131 \cdot 1 \pm 3 \cdot 9 \\
127 \cdot 5 \pm 2 \cdot 7\end{array}$ & $\begin{array}{l}120 \cdot 8 \pm 3 \cdot 8 \\
115 \cdot 9 \pm 4 \cdot 0\end{array}$ & $\begin{array}{l}-7 \cdot 3 \\
-8 \cdot 8^{*}\end{array}$ & $\begin{array}{c}-6 \cdot 8 \\
-10 \cdot 1^{*}\end{array}$ \\
\hline $\begin{array}{ll}\text { Low dose } & \ldots \\
\text { High dose } & .\end{array}$ & $\because$ & $\begin{array}{l}94 \cdot 9 \pm 2 \cdot 3 \\
92 \cdot 9 \pm 2 \cdot 3\end{array}$ & $\begin{array}{l}88 \cdot 6 \pm 2 \cdot 5 \\
86 \cdot 7 \pm 2 \cdot 0\end{array}$ & $\begin{array}{l}89 \cdot 0 \pm 2 \cdot 0 \\
86 \cdot 2 \pm 1 \cdot 7\end{array}$ & $\begin{array}{l}83 \cdot 1 \pm 2 \cdot 1 \\
77 \cdot 8 \pm 1 \cdot 8\end{array}$ & $\begin{array}{l}-6 \cdot 1 * * \\
-7 \cdot 4^{* * *}\end{array}$ & $\begin{array}{l}-5 \cdot 7^{* *} \\
-7 \cdot 8^{* * *}\end{array}$ \\
\hline
\end{tabular}

${ }^{*} \mathrm{p}<0.05 ; * * \mathrm{p}<0.01 ; * * \mathrm{p}<0.001$

TABLE II-Breakdown of response of supine blood pressure to treatment: patients grouped according to blood pressure on placebo

\begin{tabular}{|c|c|c|c|c|c|c|c|c|}
\hline \multirow{2}{*}{$\begin{array}{l}\text { Blood pressure } \\
\text { on placebo } \\
(\mathrm{mm} \mathrm{Hg})\end{array}$} & \multirow{2}{*}{$\begin{array}{c}\text { No } \\
\text { of } \\
\text { patients }\end{array}$} & \multirow{2}{*}{$\begin{array}{c}\text { Mean } \\
\text { on } \\
\text { placebo }\end{array}$} & \multicolumn{2}{|c|}{ Propranolol } & \multicolumn{2}{|c|}{ Nifedipine } & \multicolumn{2}{|c|}{ Combination } \\
\hline & & & Mean & $\begin{array}{c}\% \\
\text { Fall }\end{array}$ & Mean & $\begin{array}{c}\% \\
\text { Fall }\end{array}$ & Mean & $\begin{array}{c}\% \\
\text { Fall }\end{array}$ \\
\hline \multicolumn{9}{|l|}{ Systolic } \\
\hline $\begin{array}{r}100-119 \\
-129 \\
-139 \\
-180\end{array}$ & $\begin{array}{l}5 \\
3 \\
5 \\
5\end{array}$ & $\begin{array}{l}116 \\
126 \\
135 \\
155\end{array}$ & $\begin{array}{l}107 \\
119 \\
133 \\
140\end{array}$ & $\begin{array}{l}8 \\
6 \\
1 \\
5\end{array}$ & $\begin{array}{l}117 \\
120 \\
133 \\
130\end{array}$ & $\begin{array}{r}-1 \\
5 \\
1 \\
16\end{array}$ & $\begin{array}{l}102 \\
105 \\
121 \\
130\end{array}$ & $\begin{array}{l}12 \\
17 \\
10 \\
16\end{array}$ \\
\hline \multicolumn{9}{|l|}{ Diastolic } \\
\hline $\begin{array}{r}75-84 \\
-94 \\
-110\end{array}$ & $\begin{array}{l}8 \\
6 \\
4\end{array}$ & $\begin{array}{r}81 \\
90 \\
103\end{array}$ & $\begin{array}{l}77 \\
81 \\
93\end{array}$ & $\begin{array}{r}5 \\
10 \\
10\end{array}$ & $\begin{array}{l}80 \\
78 \\
88\end{array}$ & $\begin{array}{l}1 \\
13 \\
15\end{array}$ & $\begin{array}{l}73 \\
71 \\
88\end{array}$ & $\begin{array}{l}10 \\
21 \\
15\end{array}$ \\
\hline
\end{tabular}

largely due to the effect of nifedipine $(60 \mathrm{mg})$, which reduced maximum pressure by $16 / 7 \mathrm{~mm} \mathrm{Hg}$. The corresponding reduction due to propranolol was not significant and averaged $7 / 2 \mathrm{~mm} \mathrm{Hg}$.

Heart rate-Nifedipine did not significantly change the resting, standing, or maximum heart rates during the cold pressor or mental arithmetic tests. Propranolol reduced the resting heart rate by 14 beats/min in the low dose and by 19 beats $/ \mathrm{min}$ in the high dose (table IV). Erect pulse rate was reduced by 19 beats/min by low-dose propranolol and 25 beats/min by high-dose propranolol, and the high dose reduced the maximum heart rate during the cold pressor and mental arithmetic tests by 22 and 26 beats/min respectively (table IV).

Side effects-The commonest side effect with nifedipine was mild ankle oedema $(p<0.05)$, while coldness of the extremities and 
paraesthesiae were most often seen with propranolol (table V). No patient developed cardiac failure or conduction abnormalities on the ECG.

\section{Discussion}

The combination of nifedipine and propranolol produced the greatest fall in both supine and erect systolic and diastolic blood pressures, but there was no interaction between the two and their effects were additive. When administered alone nifedipine reduced supine systolic and diastolic blood pressure slightly more than did propranolol (table I). Despite the exclusion of hypertensive patients at entry, six nevertheless had resting systolic blood pressures of $140-190 \mathrm{~mm} \mathrm{Hg}$ and six had resting diastolic pressures of $90-105 \mathrm{~mm} \mathrm{Hg}$ during the placebo phase. The greater the blood pressure on placebo (systolic and diastolic), the greater the reduction obtained with nifedipine, whether measured in absolute units or as a percentage of the placebo value. This was not seen with propranolol or the combination (table II). Our data showed that a sharp reduction in blood pressure is not to be expected in normotensive subjects. This is consistent with the findings in one study ${ }^{6}$ on young normotensive subjects, in whom nifedipine produced a rise in heart rate but no fall in blood pressure. Interestingly only nifedipine significantly lowered the maximum blood pressure achieved after performing mental arithmetic. Propranolol tended to have the same effect, and the differences between the drugs might have been due to a failure to use equipotent doses. Against this, the effects on standing pressure of $30 \mathrm{mg}$ of nifedipine and $240 \mathrm{mg}$ of propranolol were very similar, as were the effects of $60 \mathrm{mg}$ nifedipine and $480 \mathrm{mg}$ propranolol. When considering the maximum blood pressure after performing mental arithmetic, however, nifedipine had over twice the hypotensive effect of propranolol.

In contrast with findings in acute studies, ${ }^{7}$ nifedipine did not significantly increase the heart rate despite significantly reducing blood pressure. To examine heart rate and blood pressure responses in individual patients, the change in heart rate with nifedipine was plotted as a function of the change in systolic blood pressure (see figure). Heart rate fell in those patients who had the greatest reductions in supine systolic blood pressure when compared with pressures on placebo. During the propranolol and combination phases, the heart rate responses in these patients were similar to those of the rest of the group.

In normal subjects ${ }^{8}$ and in patients with ischaemic heart disease $^{9}$ intravenous or sublingual nifedipine appears to have no direct depressant effect on the sinus node. Indeed, in acute studies nifedipine increases the sinus rate, probably secondary to reflex sympathetic response. An electrophysiological effect is therefore unlikely to account for our findings.

Bristow et $a l^{10}$ have shown reduced sensitivity of the baroreceptors in hypertensive patients with respect to controlling heart rate: hypertensive patients have a reduced ability to

TABLE III-Blood pressure responses to cold pressor and mental arithmetic tests during treatment with propranolol, nifedipine, and their combination (high doses)

\begin{tabular}{|c|c|c|c|c|c|c|}
\hline & \multicolumn{4}{|c|}{ Mean $( \pm \mathrm{SEM})$ blood pressures $(\mathrm{mm} \mathrm{Hg})$ on: } & \multirow{2}{*}{$\underset{\text { propranolol }}{\text { Effect of }}$} & \multirow{2}{*}{$\begin{array}{c}\text { Effect of } \\
\text { nifedipine }\end{array}$} \\
\hline & Placebo & Propranolol & Nifedipine & Combination & & \\
\hline $\begin{array}{l}\text { Cold pressor test } \\
\text { Maximum systolic pressure } \\
\text { Maximum rise in systolic pressure } \\
\text { Maximum diastolic pressure } \\
\text { Maximum rise in diastolic pressure }\end{array}$ & $\begin{array}{r}168 \cdot 6 \pm 5 \cdot 3 \\
30 \cdot 2 \pm 3 \cdot 4 \\
109 \cdot 8 \pm 3 \cdot 7 \\
25 \cdot 1 \pm 3 \cdot 2\end{array}$ & $\begin{array}{r}160 \cdot 1 \pm 7 \cdot 3 \\
32 \cdot 0 \pm 3 \cdot 1 \\
99 \cdot 1 \pm 2 \cdot 1 \\
18 \cdot 9 \pm 1 \cdot 9\end{array}$ & $\begin{array}{rl}152 \cdot 2 & \pm 4 \cdot 2 \\
28 \cdot 2 & \pm 2 \cdot 7 \\
95 \cdot 3 & 2 \cdot 6 \\
15 \cdot 9 & 1 \cdot 7\end{array}$ & $\begin{array}{r}138 \cdot 6 \pm 4 \cdot 0 \\
22 \cdot 8 \pm 3 \cdot 2 \\
93 \cdot 2 \pm 2 \cdot 8 \\
16 \cdot 8 \pm 2 \cdot 1\end{array}$ & $\begin{array}{l}-11 \cdot 0^{*} \\
-1 \cdot 9 \\
-6 \cdot 4^{*} \\
-2 \cdot 7\end{array}$ & $\begin{array}{l}-19 \cdot 0^{* * *} \\
-5 \cdot 6 \\
-10 \cdot 2^{* * *} \\
-5 \cdot 7^{*}\end{array}$ \\
\hline $\begin{array}{l}\text { Mental arithmetic test } \\
\text { Maximum systolic pressure } \\
\text { Maximum rise in systolic pressure } \\
\text { Maximum diastolic pressure } \\
\text { Maximum rise in diastolic pressure }\end{array}$ & $\begin{aligned} 157 \cdot 2 & \pm 5 \cdot 2 \\
27 \cdot 7 & \pm 3 \cdot 2 \\
99 \cdot 2 & \pm 2 \cdot 2 \\
17 \cdot 0 & \pm 3 \cdot 1\end{aligned}$ & $\begin{array}{r}152 \cdot 9 \pm 7 \cdot 1 \\
25 \cdot 6 \pm 3 \cdot 3 \\
96 \cdot 1 \pm 2 \cdot 8 \\
17 \cdot 1 \pm 2 \cdot 4\end{array}$ & $\begin{array}{rl}143 \cdot 8 & \pm 3 \cdot 9 \\
22 \cdot 7 & \pm 3 \cdot 2 \\
91 \cdot 4 & 2 \cdot 4 \\
13 \cdot 6 & 2 \cdot 1\end{array}$ & $\begin{aligned} & 133.9 \pm 4.5 \\
& 21.1 \pm 2.7 \pm 0.4 \pm 3.1 \\
& 13.9 \pm 1.9\end{aligned}$ & $\begin{array}{l}-7 \cdot 1 \\
-1 \cdot 9 \\
-2 \cdot 1 \\
+0.2\end{array}$ & $\begin{array}{l}-16 \cdot 2 * * \\
-4 \cdot 8 \\
-6 \cdot 7^{*} \\
-3 \cdot 3\end{array}$ \\
\hline
\end{tabular}

${ }^{*} \mathrm{p}<0.05 ;{ }^{* *} \mathrm{p}<0.01 ; * *{ }^{* *} \mathrm{p}<0.001$

TABLE IV-Response of heart rate, supine and erect, and during cold pressor and mental arithmetic tests, to treatment with propranolol, nifedipine, and their combination

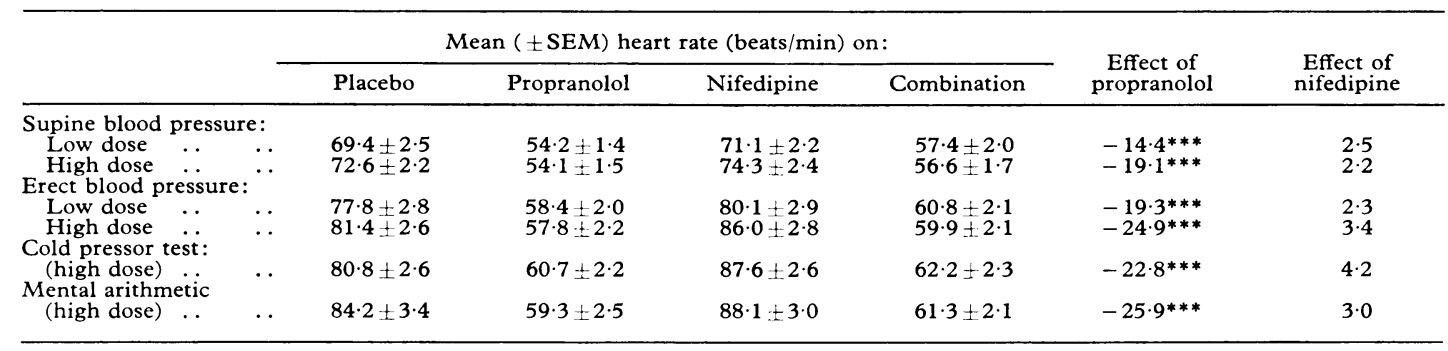

${ }^{*} \mathrm{p}<0.05 ;{ }^{* *} \mathrm{p}<0.01 ;{ }^{* * *} \mathrm{p}<0.001$.

TABLE $\mathrm{V}-$ Side effects and numbers (and percentages) of patients experiencing them during treatment with propranolol, nifedipine, and their combination

\begin{tabular}{lrrrr}
\hline & Placebo & Nifedipine & Propranolol & Combination \\
\hline $\begin{array}{l}\text { Faintness on } \\
\text { standing }\end{array}$ & $3(17)$ & $7(39)$ & $4(22)$ & $5(28)$ \\
$\begin{array}{l}\text { Weakness in limbs } \\
\text { Nausca-anorexia }\end{array}$ & $4(22)$ & $5(28)$ & $4(22)$ & $7(39)$ \\
Headaches & $6(33)$ & $6(33)$ & $1(6)$ & $17(6)$ \\
Sleepy during day & $12(67)$ & $11(61)$ & $11(61)$ & $7(39)$ \\
Sleep disturbance & $1(6)$ & $5(28)$ & $5(28)$ & $5(28)$ \\
Cold fingers or & $5(28)$ & $3(17)$ & $9(50)$ & $6(33)$ \\
toes & $2(11)$ & $11(61)$ & $4(22)$ & $8(44)$ \\
\hline
\end{tabular}

reduce heart rate in response to phenylephrine-induced hypertension. A similar finding was observed in patients with heart disease $^{11}$; patients with heart disease also do not have the same ability as normal people to increase heart rate when the parasympathetic system is inhibited by atropine, suggesting that parasympathetic cardiovascular regulation is abnormal in heart disease. As all of our patients had ischaemic heart disease and six had some increase in systolic blood pressure, we could not determine whether the heart rate-blood pressure responses with nifedipine reflected abnormal autonomic regulation or true physiological resetting of the baroreceptors. 


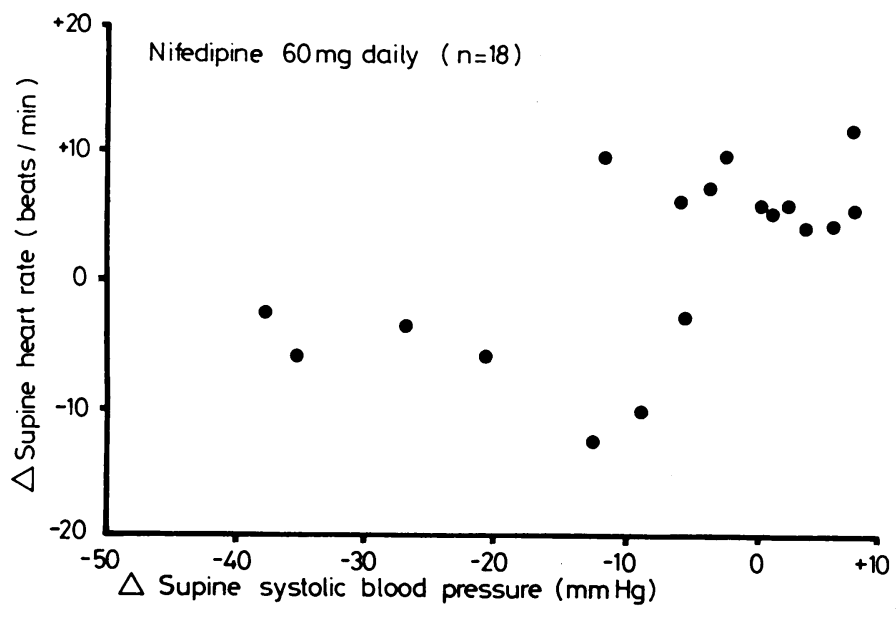

Supine heart rate versus supine systolic blood pressure: change from placebo to nifedipine ( $60 \mathrm{mg} / \mathrm{day})$.

In our previous report ${ }^{4}$ we showed that both nifedipine and propranolol were effective in managing angina of effort but that the combination was significantly better than either drug alone. Though it has been suggested that a reduction in blood pressure in patients with coronary artery disease may precipitate angina or ischaemia by reducing myocardial blood flow, the phase which produced the greatest fall in blood pressure also produced the greatest reduction in angina. Hypertension and ischaemic heart disease often co-exist and hypertension predisposes to and possibly aggravates atherosclerotic vascular disease. ${ }^{12} \mathrm{~A}$ regimen that lowers blood pressure and effectively improves ischaemia is thus advantageous. The combination of propranolol and nifedipine satisfies this need.

The hypotensive potential of beta-blocking agents was first noted during a clinical trial of propranolol in patients with angina pectoris. ${ }^{13}$ The favourable haemodynamic responses to calcium antagonists will probably also prove valuable in managing patients with hypertension.

Requests for reprints should be sent to Dr D M Krikler.

\section{References}

${ }^{1}$ Fleckenstein A. Specific inhibitors and promoters of calcium action in the excitation-contraction coupling of heart muscle and their role in the prevention or production of myocardial lesions. In: Harris $P$ Opie LH, eds. Calcium and the heart. London, New York: Academic Press, 1971:135-8.

${ }^{2}$ Fleckenstein A. Specific pharmacology of calcium in myocardium, cardiac pacemakers and vascular smooth muscle. Annu Rev Pharmacol Toxicol 1977;7:149-66.

${ }^{3}$ Wei JW, Jarvis RA, Daniel EE. Alterations in calcium transport and binding by the plasma membrane of mesenteric arteries from spontaneously hypertensive rats. Blood Vessels 1977;14:55-64.

${ }^{4}$ Lynch P, Dargie H, Krikler S, Krikler D. Objective assessment of anti-anginal treatment: a double-blind comparison of propranolol, nifedipine and their combination. $\mathrm{Br}$ Med f 1980;280:184-7.

${ }^{5}$ Armitage P. Statistical methods in medical research. Oxford: Blackwell Scientific, $1971: 266$

- MacGregor GA. Evidence from studies with nifedipine of a functional abnormality of smooth muscle in essential hypertension. In: Richardson RG, ed. National cardiovascular symposium: the role of calcium antagonists in cardiovascular disease. Haywards Heath: Bayer UK, 1982.

${ }^{7}$ Guazzi M, Olivari MT, Polese A, et al. Nifedipine, a new antihypertensive agent with rapid action. Clin Pharm Ther 1977;22:528-32.

${ }^{8}$ Rowland E, Evans T, Krikler D. Effect of nifedipine on atrioventricular conduction as compared with verapamil. Br Heart $\mathcal{f} 1979 ; 42: 124-7$.

- Kawai C, Kanishi T, Matsuyama E, Okazaki H. Comparative effects of three calcium antagonists, diltiazem, verapamil and nifedipine, on the sinoatrial and atrioventricular nodes. Circulation 1981;63:1035-42.

${ }^{10}$ Bristow JD, Honour AJ, Pickering G, Sleight P, Smyth HS. Diminished baroreflex sensitivity in high blood pressure. Circulation 1969;39:48-54.

11 Eckberg DL, Drabinsky M, Braunwald E. Defective cardiac parasympathetic control in patients with heart disease. $N$ Engl $f$ Med $1971 ; 285: 877-83$

${ }^{12}$ Kannel WB. Role of blood pressure in cardiovascular disease: The Framingham study. Angiology $1975 ; 26: 1-14$.

13 Prichard BNC, Gillam PMS. Use of propranolol (Inderal) in treatment of hypertension $\mathrm{Br}$ Med $\mathcal{7}$ 1964;2:725-7.

(Accepted 14 fanuary 1981)

\title{
Acute haemolysis due to concentrated dialysis fluid
}

\author{
I MULLIGAN, P PARFREY, M E PHILLIPS, E A BROWN, J R CURTIS
}

\begin{abstract}
Fatal acute haemolysis occurred in a 65-year-old man undergoing regular home haemodialysis for terminal renal failure. Circumstantial evidence indicating that the haemolysis resulted from exposure to concentrated dialysis solution was supported by in-vitro studies. Frank haemolysis in blood samples occurred at a dilution of $>1 / 2$ of dialysis fluid. Osmotic fragility tests of surviving red blood cells showed $47 \%$ haemolysis at a dilution of $1 / 2$ and $>90 \%$ haemolysis at a dilution of $1 / 1$. Urgent design modifications to the proportionating machine are being undertaken to prevent such an accident recurring.
\end{abstract}

Department of Medicine, Charing Cross Hospital Medical School, London W6 8RF

I MULLIGAN, BM, senior house officer

P PARFREY, MD, MRCP, lecturer

M E PHILLIPS, MD, MRCP, senior lecturer

E A BROWN, BM, MRCP, senior registrar

J R CURTIS, MD, FRCP, consultant nephrologist and senior lecturer

\section{Introduction}

Acute haemolysis is a rare complication of haemodialysis. There are a wide variety of medical and drug-related causes of haemolysis which may occur incidentally in patients undergoing maintenance haemodialysis. Several technical causes may also complicate haemodialysis and result in acute haemolysis. These include dialysis against hypotonic dialysis fluid, contamination of dialysis fluid by toxic concentrations of copper, zinc, chloramine, nitrate, and formaldehyde ${ }^{1}$ and haemolysis due to overheated dialysate. ${ }^{2}$ We report the case of a patient who developed acute haemolysis as a result of exposure to very concentrated dialysis fluid.

\section{Case report}

A 65-year-old man had started regular twice weekly haemodialysis in July 1977 because of terminal renal failure due to rapidly progressive glomerulonephritis. He started on home dialysis in May 1978 and dialysed for 10 hours twice weekly using a Meltec Multipoint dialyser $\left(1.05 \mathrm{~m}^{2}\right)$ and a single pass Dylade DII proportionating machine. On the day of admission to hospital in May 1981 